\title{
COFEFSPONDFINCF.
}

\section{A NEW LAKE IN THE PISTOJESE MOUNTAINS.}

SrR,-An inferesting example of lake-formation has recently been noticed in one of the valleys of the Apennines by my friend Captain Cecil Norton, 5th Lancers. The road from Florence by Pistoja to Modena crosses the mountain-range at Boscolungo, where the limestone rocks form a semicircular arc, facing the south; and from the northern side of this ridge a spur juts out towards the north-east, and forms a V-shaped valley, giving rise to a small tributary of the river on which Modena is situated. On the neighbouring heights the snow occasionally lies until late in the year. During the last summer, as late as August 25th, snow was lying near Abetone, the mountain-top of Boscolungo, and about 4,500 feet high; also away eastward, on the hill-tops on the southern side of the gorge beyond Monte Cimone, which is the crest, 6,700 feet high, at the head of the valley above mentioned. As in the Alps and elsewhere, these Italian snows are subject to sudden meltings, though it is said to be fifty years since so rapid a thaw, or such a flood of snowwater, has been recorded as that of this year. The mountains here, it will be remembered, are composed of limestone and sandy macigno, and therefore so highly susceptible of frost-action that the accumulation of débris on and at the foot of the slopes is often considerable. Some time in June last so sudden and rapid a melting of the snow occurred as to sweep down a large mass of débris, sufficient indeed to completely block the bed of the rivulet above mentioned, forming one of the head-waters of the Modena river. The result was the formation of a lake, some 300 or 400 yards long, by 150 or 200 yards wide, at the time when it was seen (from the pass) on the 24th August.

It will be interesting to notice hereafter what effect the retention of the water will have on the dam of this little lake. Will the dam be violently cut through, or totally swept away, by gradually accumulated water? Will it be strong enough to withstand the pressure? Will it be quietly worn down by the overflow, so as to allow of the gradual lowering of the lake? Will it be undermined by the destruction of its lower part? In any case the débris left will be moraine-like in character; and might, but for the want of the regular strice, be mistaken for the results of an old glacier.

Thus, it may be instructive to place on record this formation of a moraine-like heap, which, without careful examination as well of detail as of general appearance and situation, might at some future time be attributed to the action of a force very different from that which brought it to its place.

T. RDPERT JONES.

Staff College, Camberiat, Sept. $16 t h, 1879$. 